\title{
Spatial distribution of the soil organic carbon pool in a Holm oak dehesa in Spain
}

\author{
Nuria Simón • Fernando Montes • Eugenio Díaz-Pinés • \\ Raquel Benavides • Sonia Roig • Agustín Rubio
}

Received: 12 April 2012 / Accepted: 23 August 2012 / Published online: 15 September 2012

(C) Springer Science+Business Media B.V. 2012

\begin{abstract}
Aims Dehesas are agroforestry systems characterized by scattered trees among pastures, crops and/or fallows. A study at a Spanish dehesa has been carried out to estimate the spatial distribution of the soil organic carbon stock and to assess the influence of the tree cover.

Methods The soil organic carbon stock was estimated from the five uppermost $\mathrm{cm}$ of the mineral soil with high spatial resolution at two plots with different grazing intensities. The Universal Kriging technique was used to assess the spatial distribution of the soil organic
\end{abstract}

Responsible Editor: Zucong Cai.

N. Simón $(\bowtie) \cdot F$. Montes $\cdot$ E. Díaz-Pinés $\cdot S$. Roig $\cdot$

A. Rubio

Silviculture and Pasciculture Department of Forestry

Faculty, Universidad Politécnica de Madrid,

28040 Madrid, Spain

e-mail: nuriasimon@hotmail.com

F. Montes

CIFOR-INIA,

Madrid, Spain

E. Díaz-Pinés

Institute of Meteorology and Climate Research, Atmospheric Environmental Research (IMK-IFU),

Karlsruhe Institute of Technology,

Garmisch-Partenkirchen, Germany

R. Benavides

National Museum of Natural Sciences - CSIC,

Madrid, Spain carbon stocks, using tree coverage within a buffering area as an auxiliary variable.

Results A significant positive correlation between tree presence and soil organic carbon stocks up to distances of around $8 \mathrm{~m}$ from the trees was found. The tree crown cover within a buffer up to a distance similar to the crown radius around the point absorbed $30 \%$ of the variance in the model for both grazing intensities, but residual variance showed stronger spatial autocorrelation under regular grazing conditions.

Conclusions Tree cover increases soil organic carbon stocks, and can be satisfactorily estimated by means of crown parameters. However, other factors are involved in the spatial pattern of the soil organic carbon distribution. Livestock plays an interactive role together with tree presence in soil organic carbon distribution.

Keywords Agroforestry systems · Universal Kriging · Spatial variance partition $\cdot$ Soil $C \cdot$ Tree effect

\section{Introduction}

Dehesas are traditional agro-silvo-pastoral ecosystems of the Iberian Peninsula, which are adapted to the unpredictability of the Mediterranean climate (Joffre et al. 1999). These multipurpose systems are the most widelyextended European agroforestry system, covering at least 4 million hectares in central and south-western Spain (Barba et al. 2008; Moreno and Pulido 2008). Overstorey of the dehesa is derived from original denser 
forests which were progressively thinned, causing a savannah-like landscape. Dehesa ecosystem is characterised by the presence of Mediterranean trees intermittently distributed without a regular pattern and has grasslands/pastures, crops, and fallows as understorey, usually in a rotation scheme (Carreiras et al. 2006; Joffre et al. 1999; Pinto-Correia 1993). The presence of livestock and shrubs and the crop-fallow cycles shows variations both between and within years. In contrast to this temporal variability, the tree layer is constantly present, providing stability and constituting a key factor for the understanding of ecosystem mechanisms (Moreno et al. 2007; Moreno and Obrador 2007).

Trees in dehesa systems induce positive effects on physical soil features (Joffre and Rambal 1988) and on soil organic matter properties (Gallardo 2003; Joffre et al. 1999; Moreno et al. 2007). In savannah-like ecosystems, such as dehesas, isolated trees provide a more comfortable and nourishing site for livestock than open areas. Similarly, growth conditions for grasses are usually more favourable below the tree crowns (Gea et al. 2009), since high radiation and temperature stress are mitigated ( $\mathrm{Li}$ et al. 2008). Moreover, isolated trees pump nutrients from deep soil horizons (Young 1997) and from areas laterally distant from the trunk (Scholes and Archer 1997), which are then recycled via leaf litter (Escudero et al. 1992; Gallardo and Merino 1998). Thus, trees drive litterfall inputs, livestock manure and rainfall distribution, soil temperature, and consequently they shift soil microbial quantity and activity. However, the extent to which the tree layer influences the soil organic carbon (SOC) stocks in dehesas is still poorly understood.

The potential of agroforestry systems in C sequestration is widely accepted (Garrity et al. 2006). In these ecosystems, aboveground biomass is relatively low compared to closed forests, and the greatest proportion of $\mathrm{C}$ is stored belowground (FAO 2004). Nevertheless, dehesas have scarcely been included in large-scale studies to assess the SOC sequestration capacity (RodríguezMurillo 2001; Rovira et al. 2007). The spatial heterogeneity of dehesas, their complex management, and their generally low SOC contents (Rodeghiero et al. 2011) may be the reason for this scant attention. However, such a vast managed system, located in an area which is highly sensitive to climate change (IPCC 2007), clearly requires a more accurate knowledge of its SOC sequestration capacity in order to ensure a better understanding of its role in mitigating global climate change through soil conservation and management.
As geostatistical analyses are able to characterise the spatial continuity of a regionalised variable, kriging techniques have been widely used to analysed the spatial distribution of soil attributes, such as the concentration of contaminants (Goovaerts 1999). The spatial variance of the variable is modelled through the variogram, which is used to calculate the optimal weights for the observed values in order to predict the value of the variable of interest at an unsampled point. In univariate kriging techniques the accuracy depends on sample size, sampling configuration, and the degree of spatial correlation of the primary variable of interest (Gotway and Stroup 1997; Laslett et al. 1987). Universal Kriging can be considered a spatial regression method (Stein and Corsten 1991) which provides the optimal linear model to incorporate auxiliary information in data analysis in the presence of spatial dependence of observations (Cressie 1993). Often, the aim is to identify the sources originating the spatial variation observed in ecological processes (Borcard et al. 1992; He et al. 1996). The spatial variability associated with the explanatory variables can be determined from variogram and the underlying function on the explanatory variables of the Universal Kriging model (Montes and Ledo 2010). Different SOC approaches have been carried out at field scale using exhaustive secondary information such as terrain index (Mueller and Pierce 2003), remote sensing (Chen et al. 2000; Lark 2000), or other soil and environmental information. However, in dehesas, where trees play an important role in the $\mathrm{C}$ cycle, the presence and distribution of trees should be considered to assess the distribution of SOC stocks.

The objectives of this study were to quantify the SOC stock $\left(\mathrm{g} \cdot \mathrm{m}^{-2}\right)$ of the five uppermost $\mathrm{cm}$ of the mineral soil and to assess the influence of the tree cover on the spatial distribution of SOC in a dehesa system. We hypothesised that the spatial pattern of the SOC stock in a dehesa is mainly driven by the spatial distribution of the tree layer, given that trees exert a strong influence on litterfall rates and environmental conditions for grasses development and soil microbes activity.

\section{Material and methods}

Study site

The study was carried out in a dehesa, located at the experimental station 'CIA Dehesón del Encinar' in 
Oropesa (Toledo, central Spain) $\left(39^{\circ} 59^{\prime} \mathrm{N}, 5^{\circ} 6^{\prime} \mathrm{W}\right)$ (Fig. 1a), at $350 \mathrm{~m}$ above sea level, and with gentle slopes $(2 \%)$. The climate is Mediterranean continental with mild winters and a severe summer drought. Mean annual temperature recorded (1988-2007) at the site is around $15.1{ }^{\circ} \mathrm{C}$ and the annual rainfall averaged $607 \mathrm{~mm}$. Soils are classified as Haplic luvisol and Haplic cambisol (IUSS Working Group WRB 2007), moderately acidic, with low SOC content and a sandy topsoil. An exploratory soil survey carried out in the study area consisting of 32 soil samples taken from the uppermost $5 \mathrm{~cm}$ (16 under tree cover and 16 outside) showed that the characteristics of the uppermost soil horizon changed depending on tree crown projection (Table 1). The grass layer yield was measured in 30 squared plots of $0.25 \mathrm{~m}^{2}$ located across the study area for 2 years. Grass layer in the dryer year $(530 \mathrm{~mm})$ ranged from $5.8-25.2$ to $39.3-51.2 \mathrm{~g} \mathrm{C} \mathrm{m}^{-2}$ year $^{-1}$ beneath and beyond the crown projection, respectively. In the more humid year $(830 \mathrm{~mm})$, however, yields were $69.5-108.8$ and $65.9-104.3 \mathrm{~g} \mathrm{C} \mathrm{m}^{-2}$ year $^{-1}$, respectively. Aboveground litterfall rates $( \pm$ standard
Fig. 1 Location of the experimental farm 'Dehesón del Encinar' (Toledo) in Spain, and location of the study plot (white square)

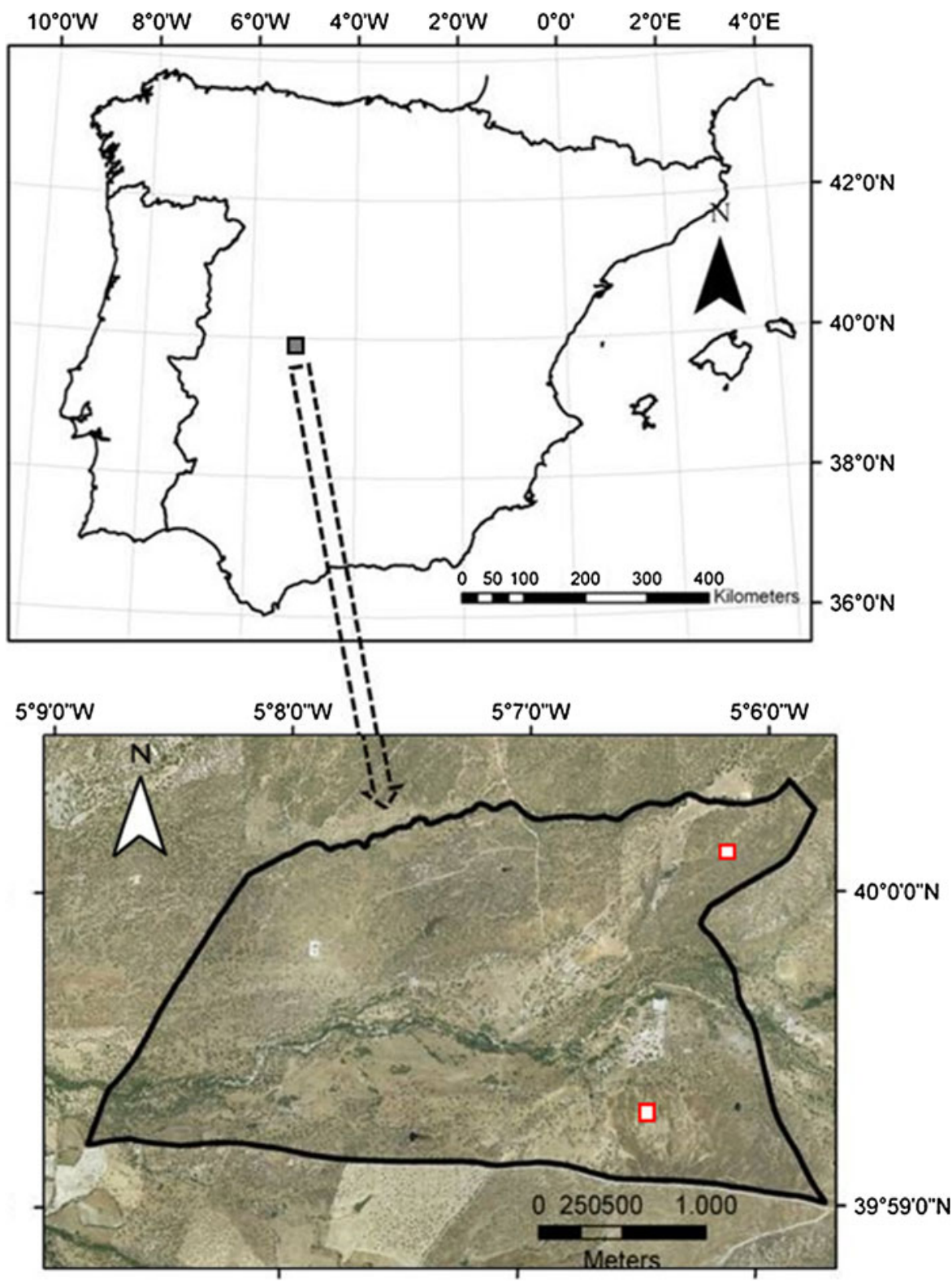


Table 1 Mean and standard deviation of soil properties in the top $5 \mathrm{~cm}$ of soil beneath tree crown $(n=16)$ and beyond the influence of the tree $(n=16)$ in the studied dehesa

\begin{tabular}{lllllllll}
\hline Zone & $\mathrm{pH}\left(\mathrm{H}_{2} \mathrm{O}\right)$ & $\mathrm{pH}(\mathrm{KCl})$ & Fine earth $(\%)$ & $\mathrm{SOC}\left(\mathrm{gkg}^{-1}\right)$ & $\mathrm{N}\left(\mathrm{gkg}^{-1}\right)$ & $\mathrm{C}: \mathrm{N}$ & $\mathrm{BD}\left(\mathrm{g} \cdot \mathrm{cm}^{-3}\right)$ & $\mathrm{SOC}\left(\mathrm{g} \cdot \mathrm{m}^{-2}\right)$ \\
\hline Beneath tree crown & $6.1 \pm 0.4$ & $5.2 \pm 0.5$ & $91.5 \pm 5.6$ & $34.2 \pm 12.5$ & $4.7 \pm 1.7$ & $7.4 \pm 2.2$ & $1.0 \pm 0.1$ & $1263 \pm 396$ \\
Beyond the tree crown & $5.7 \pm 0.3$ & $4.4 \pm 0.3$ & $93.0 \pm 4.3$ & $13.6 \pm 0.3$ & $2.4 \pm 0.6$ & $5.9 \pm 1.0$ & $1.3 \pm 0.2$ & $521 \pm 133$ \\
\hline
\end{tabular}

SOC: Soil Organic Carbon. N: Total Nitrogen; C:N: carbon-nitrogen ratio; BD: Bulk density

deviation) were $932( \pm 425) \mathrm{g} \mathrm{C} \mathrm{m}^{-2}$ year $^{-1}$ below the tree crowns, litterfall being negligible in open areas between the trees.

The study was conducted in two plots (Fig. 1b) under different sheep grazing intensities: a $100 \times 100 \mathrm{~m}$ plot regularly grazed (hereafter $\mathrm{RG}$ ), which carried a 3.5 sheep $\cdot$ ha $^{-1}$ equivalent grazing intensity from mid-April to June, and a $72 \times 100 \mathrm{~m}$ plot occasionally grazed (hereafter OG), where similar grazing intensity is intermittently distributed across the whole year (Fig. 1b). The grass layer vegetation comprises subnitrophilous pastures of the Sisymbrietalia officinalis R.Tx. order at the RG plot and annual pastures included in the Tuberarietalia guttatae $\mathrm{Br}$-B1. order at the OG plot. Both plots have a scattered tree layer consisting of Holm oaks (Quercus ilex subsp. ballota (Desf.) Samp.).

\section{Sampling design}

61 points were randomly established at RG and 231 at OG. Soil samples were taken from the top $0-5 \mathrm{~cm}$ after removing stones, visible plant roots and litter from the surface layer. This depth was chosen on the basis of previous studies (Rodeghiero et al. 2011) which reported that SOC stocks in deeper layers were significantly lower than in the uppermost $5 \mathrm{~cm}$. At each sample point, three soil cores were collected using a steel cylinder $(5 \mathrm{~cm}$ diameter, $5 \mathrm{~cm}$ height) and soil samples were appropriately transported to the lab.

The diameter, crown and height of every tree in the plot were measured, as well as their geographical position in the respective plots with an accuracy of $10 \mathrm{~cm}$. The main tree features are shown in Table 2.

Soil analysis

Soil bulk density $\left(\mathrm{g} \cdot \mathrm{cm}^{-3}\right)$ was assessed through the extraction of undisturbed soil cores in accordance with
Blake and Hartge (1986). The Loss On Ignition method (Nelson and Sommers 1996) was used to estimate the soil organic matter content, measuring the loss of weight after ignition with a furnace-oven at $405{ }^{\circ} \mathrm{C}$ for 4 h. $20 \%$ of the samples were in addition analysed with a total organic carbon analyser (TOC-5000, Shimadzu Corporation, Kyoto, Japan), equipped with a solid sample module (SSM-5000, Shimadzu Corporation). Thus, $54 \%$ of the soil organic matter was considered SOC for both plots $\left(R^{2}=0.99\right)$. Fine earth content $(<2 \mathrm{~mm})$ was assessed at around $88.4 \%(\mathrm{RG})$ and $81.6 \%(\mathrm{OG})$, soil bulk density at $1.3 \mathrm{~g} \cdot \mathrm{cm}^{-3}(\mathrm{RG})$ and $1.1 \mathrm{~g} \cdot \mathrm{cm}^{-3}(\mathrm{OG})$ and SOC content at $17 \mathrm{~g} \cdot \mathrm{kg}^{-1}(\mathrm{RG})$ and $18 \mathrm{~g} \cdot \mathrm{kg}^{-1}$ (OG). Finally, the SOC stocks $\left(\mathrm{g} \cdot \mathrm{m}^{-2}\right)$ were calculated using the constant mass approach in which SOC stocks are compared in terms of equal mass instead of equal depth (Ellert and Bettany 1995). The heaviest sample from each plot was used as the mass reference. Further information can be found in Table 3.

Assessment of the spatial correlation between the SOC and the tree pattern

In order to identify the scale of the spatial correlation (positive or negative) between the tree distribution in the experimental plot (a spatial point process) and the

Table 2 Main tree characteristics in the regularly grazed plot and the occasionally grazed plot

\begin{tabular}{lll}
\hline \multicolumn{3}{c}{ Plots } \\
\hline Parameter & Regularly grazed & Occasionally grazed \\
Tree density $\left(\mathrm{n}^{\mathrm{o}} \cdot \mathrm{ha}^{-1}\right)$ & 23.0 & 41.6 \\
DBH $(\mathrm{cm})$ & $59.4 \pm 18.4$ & $34.1 \pm 19.8$ \\
Crown radius $(\mathrm{m})$ & $4.3 \pm 0.7$ & $4.2 \pm 1.3$ \\
Tree height $(\mathrm{m})$ & $8.4 \pm 2.0$ & $8.2 \pm 2.0$ \\
\hline
\end{tabular}

$\mathrm{DBH}=$ trunk diameter at breast height $(1.3 \mathrm{~m}$ height $)$ 
Table 3 Mean \pm standard error (SE), min, median and max of some soil properties at the regularly grazed plot (RG) and occasionally grazed plot $(\mathrm{OG})$ in a Dehesa ecosystem (values from the top $5 \mathrm{~cm}$ of the soil profile)

\begin{tabular}{|c|c|c|c|c|c|c|c|c|c|c|}
\hline & \multicolumn{2}{|c|}{ Mean } & \multicolumn{2}{|l|}{ SE } & \multicolumn{2}{|l|}{ Min } & \multicolumn{2}{|c|}{ Median } & \multicolumn{2}{|l|}{ Max } \\
\hline & RG & OG & $\mathrm{RG}$ & OG & $\mathrm{RG}$ & OG & RG & OG & $\mathrm{RG}$ & OG \\
\hline Fine earth content $(\%)$ & 88.4 & 81.6 & 7.5 & 4.5 & 60 & 70 & 91 & 81 & 96 & 94 \\
\hline $\mathrm{BD}\left(\mathrm{g} \cdot \mathrm{cm}^{-3}\right)$ & 1.3 & 1.1 & 0.1 & 0.1 & 1.1 & 0.7 & 1.3 & 1.1 & 1.5 & 1.4 \\
\hline $\operatorname{SOC}\left(g \cdot \mathrm{kg}^{-1}\right)$ & 17 & 18 & 6 & 6 & 8 & 5 & 15 & 15 & 38 & 48 \\
\hline
\end{tabular}

SOC stocks (a sampled continuous variable), the $K_{r x}(d)$ function (Montes and Cañellas 2007) was used:

$$
\begin{aligned}
K_{r x} & =\frac{\left(\sum_{i=1}^{N} \sum_{j=1}^{n} \omega_{i j}(d) \cdot\left[\frac{\left(x_{j}-\bar{x}\right)}{s_{x}}\right]+\sum_{i=1}^{n} \sum_{j=1}^{N} \omega_{j i}(d) \cdot\left[\frac{\left(x_{j}-\bar{x}\right)}{s_{x}}\right]\right)}{\sum_{i=1}^{N} \sum_{j=1}^{n} \omega_{i j}(d)+\sum_{i=1}^{n} \sum_{j=1}^{N} \omega_{j i}(d)} \\
S_{x}^{2} & =\frac{\sum_{j=1}^{n}\left(x_{j}-\bar{x}\right)^{2}}{n}
\end{aligned}
$$

where $N$ is the number of trees, $n$ is the number of samples where the variable was measured, $x_{j}$ is the value of the variable (SOC) in sample $j$, is the mean of the variable in the study area and $\omega_{i j}$ gives 0 if $i$ tree and soil sample $j$ are further from each other than distance $d$; otherwise, it gives the inverse of the fraction within the plot of a circumference centred on $i$, with the radius being the distance from $i$ to $j$ (Goreaud and Pélissier 1999; Ripley 1977).

The null hypothesis of spatial independence between the trees and SOC in the experimental plots was tested by using the toroidal shift model, carrying out 999 simulations, leaving the tree distribution unchanged and shifting the SOC values in the sampling points by a random vector (Wiegand and Moloney 2004). This model allows the spatial independence between the point process (the tree distribution) and the sampled variable (the SOC values) to be tested, taking into account the spatial pattern characteristic of each. The p-values were calculated in order to test the significance of the deviation from the null model (Loosmore and Ford 2006).

\section{Geostatistical analysis}

The SOC in the upper soil horizon was modelled using the Universal Kriging model, which allows the effect of the trees to be incorporated through known auxiliary variables for the sampled and unsampled points.

The Universal Kriging model is given by the following expression:

$Z\left(s_{0}\right)=\sum_{k=0}^{p} \beta_{k} f_{k}\left(s_{0}\right)+\delta\left(s_{0}\right)$

where $Z\left(s_{0}\right)$ is the value of the variable SOC at location $s_{0}, f_{k}\left(s_{0}\right)$ are $p+1$ known auxiliary variables, which, multiplied by the $\beta_{k}$ coefficients constitutes the mean function of the variable $Z$, and $\delta\left(s_{0}\right)$ is an intrinsically stationary zero-mean residual random process. The auxiliary variable considered to incorporate the effect of the trees in SOC distribution was the tree crown cover within a buffer area around the point (Fig. 2). The width of the buffer was derived from the correlation distance determined by the $K_{r x}(d)$ function.

The variable was interpolated on a $2 \times 2 \mathrm{~m}$ grid covering both plots. The Universal Kriging prediction $p\left(Z, s_{0}\right)$ of the variable $Z\left(s_{0}\right)$ is given as a linear

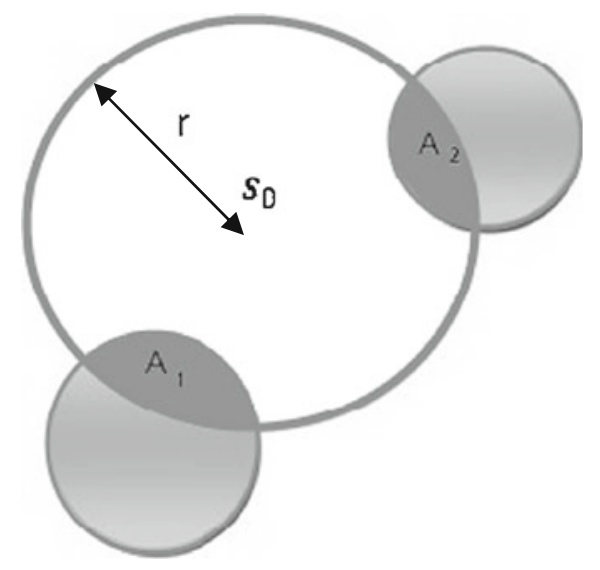

Fig. 2 Auxiliary variable calculus: method used to quantify the crown cover within a buffer zone of $r$ radius around the tree sampling point $s_{0}$ (white cirle). Dark grey circles represent the crown projection; the crown cover is calculated as $\left(\mathrm{A}_{1}+\mathrm{A}_{2}\right) / \mathrm{pi} \cdot \mathrm{r}^{2}$ 
combination of the values of the variable $Z$ at the sampled points $s_{i}(\mathrm{i}=1 \ldots \mathrm{n})$

$p\left(Z, s_{0}\right)=\sum_{i=1}^{n} \lambda_{i} \cdot Z\left(s_{i}\right)$

where each $\lambda_{i}$ is the weight for the observed value $Z$ $\left(s_{i}\right)$. To obtain unbiased estimates, $\lambda_{i}$ must satisfy the following condition:

$\sum_{i=1}^{n} \lambda_{i} \cdot f_{k}\left(s_{i}\right)=f_{k}\left(s_{0}\right) \quad k=0 \ldots p$

$f_{0}\left(s_{i}\right) \equiv 1 \quad \forall \quad i$

The spatial autocorrelation of the variable $\mathrm{Z}$ can be characterised through the semivariance (Matheron 1973):

$\widehat{\gamma}(d)=\frac{1}{2 \cdot N(d)} \sum_{i=1}^{N(d)}\left[\delta\left(s_{i}\right)-\delta\left(s_{i}+d\right)\right]^{2}$

where $N(d)$ is the number of pairs of data at $d$ distance from each other, $\delta\left(s_{i}\right)$ is the value that the residual takes at $s_{i}$ location, and $\delta\left(s_{i}+\mathrm{d}\right)$ is the value of the residual at a point which is at $d$ distance from $s_{i}$. The semivariance as a function of the distance is known as the variogram $\widehat{\gamma}(d)$. Restricted Maximum Likelihood was used to estimate the variogram parameters and the $\beta$ coefficients (Harville 1974). The spherical variogram (Goovaerts 1999) was used to model the experimental variograms obtained.

Block Universal Kriging was used to estimate mean SOC storage both beneath and beyond the influence of the tree crown and the standard error of estimation was derived from the Block Universal Kriging variance $\left(\sigma_{U K}^{2}\right)$.

As the Universal Kriging model accuracy depends on the sample, cross-validation is commonly used to assess the performance of the model because this technique does not require leaving out of the model fit any sampled value for the validation data set. The prediction bias was evaluated through the sum of the estimation errors (SEE) (Cressie 1993):

$\mathrm{SEE}=\frac{\sum_{i=1}^{n}\left(p^{*}\left(Z, s_{i}\right)-Z\left(s_{i}\right)\right)}{n}$

where $n$ is the number of observations and $p^{*}\left(Z, s_{i}\right)$ is the prediction of $Z\left(s_{i}\right)$ leaving out the value observed at $s_{i}$. SEE should approximate to 0 as our estimations are unbiased.

In order to assess the fraction of the variance explained by the auxiliary variables, Montes and Ledo (2010) proposed the following decomposition of the spatial variance:

$E\left(Z\left(s_{i}\right)-Z\left(s_{j}\right)\right)^{2}=2 \gamma\left(s_{i}-s_{j}\right)+\left(\beta_{1}\left(f_{1}\left(s_{i}\right)-f_{1}\left(s_{j}\right)\right)\right)^{2}$

In this variance partitioning approach, the trend in the variogram of $Z$ (SOC) which is usually linked to non-stationarity is modelled as a linear combination of $\gamma\left(s_{i}-s_{j}\right)$ (the variogram between locations $s_{i}$ and $s_{j}$ of the zero-mean intrinsically stationary random process $\delta\left(s_{i}\right)$, which can be estimated through the variogram parameters), and the squared differences of the explanatory variable $f_{1}$ (the crown cover within a buffer of $4 \mathrm{~m}$-width around the sampling point) multiplied by its respective $\beta_{1}$ coefficient. The empirical variogram of the variable $Z(s)$, given by $\frac{1}{2} \cdot N(d) \sum_{i=1}^{N(d)}\left[Z\left(s_{i}\right)-Z\left(s_{i}+d\right)\right]^{2}$, which stands for the total variation of the variable at distance $\mathrm{d}$, can be decomposed in the fraction of the total variation explained by $\widehat{\gamma}(d)$, and the variation linked to the explanatory variables.

Software employed

The spatial analysis calculations were computed using several scripts developed by the authors on Visual Basic (C) Microsoft Corporation. The prediction maps were built by using ArcGis 10.0 (ESRI, inc., Redlands, CA).

\section{Results}

The $K_{r x}(d)$ function revealed a significant positive correlation between tree presence and SOC values $(p<0.05)$ up to distances of approximately $8 \mathrm{~m}$ from the trunks of the trees (Fig. 3) in RG and OG plots. The correlation peaked around the middle of this interval, indicating the existence of an influence area around the trees (probably associated with tree crown cover) where higher SOC concentrations as well as SOC stocks were found. Thus, in order to model the effect of tree crowns on the SOC value at a given point, the cover within buffer area around the point seems to be more appropriate than a 
Fig. 3 The solid line represents the $K_{r x}(d)$ function between the tree pattern and the SOC sample. The dashed lines and the dotted lines represent $97.5 \%$ and $2.5 \%$ quantiles respectively of the toroidal rotation null model for the more regularly grazed plot (a) and for the occasionally grazed plot (b) a

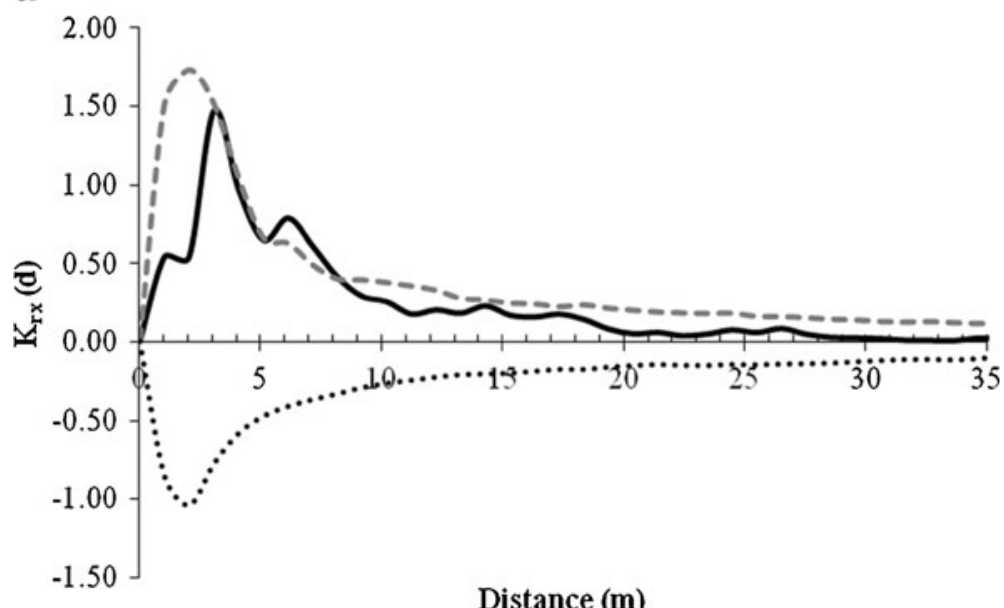

Distance (m)

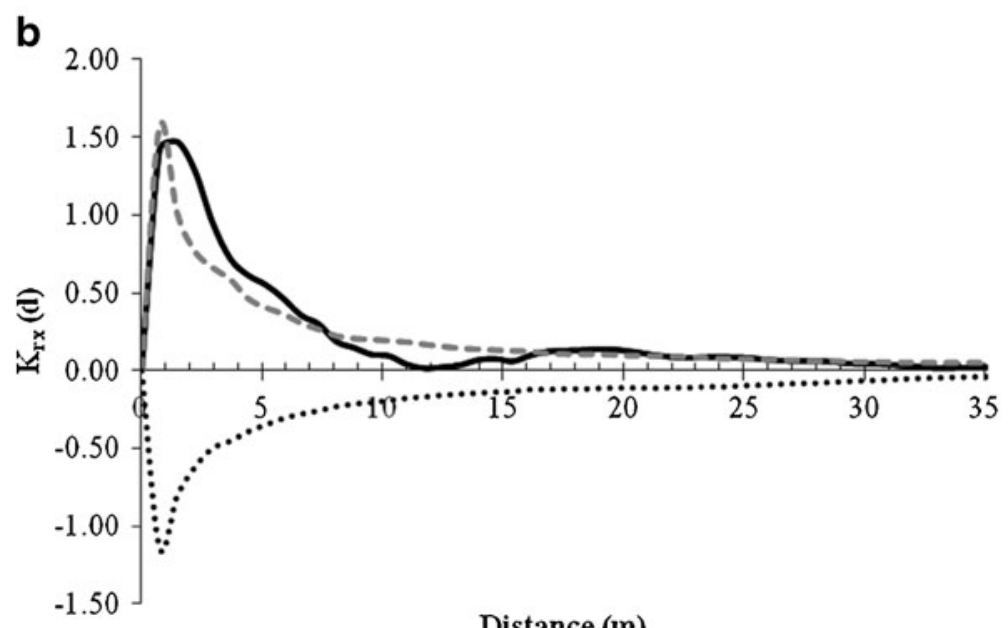

Distance (m) linear decrease of SOC with the distance to the tree trunk. Since the mean tree crown radius was approximately $4 \mathrm{~m}$ in both plots, the buffering distance considered to incorporate the effect of the trees in SOC distribution was $4 \mathrm{~m}$ (the difference between the correlation distance determined by the $K_{r x}(d)$ function and the mean crown radius).

The null nugget effect in the fitted variogram (value of the variance in the origin) indicated a higher spatial continuity in the distribution of SOC stocks in the RG plot than in the OG plot (Table 4; Fig. 4). The range of spatial autocorrelation (distance at which the variance becomes stable) of the SOC variable was also larger in the RG plot $(11.3 \mathrm{~m})$ than in the OG plot $(7.6 \mathrm{~m})$. The $\beta_{1}$ coefficient for the auxiliary variable reflected the positive association between the SOC stock and tree cover (Table 4 ) in a $4 \mathrm{~m}$ buffer around the point. The spatial pattern of tree cover explains a part of the spatial variation of the variable SOC. In Fig. 4, the spatial variance was partitioned among the variance explained by the auxiliary variable (30\% and $27 \%$ of the semivariance of the variable SOC stock in RG and $\mathrm{OG}$ respectively), and the semivariance of the residual

Table 4 Universal kriging model spherical variogram parameters and mean function coefficients. $\beta_{0}$ is the $f_{0}(s) \equiv 0$ coefficient and $\beta_{1}$ is the coefficient of (the tree crown cover in a $4 \mathrm{~m}$ buffer around the point) in the regularly grazed plot (RG) and occasionally grazed plot (OG)

\begin{tabular}{llllllr}
\hline Plot & $\begin{array}{l}\text { Nugget } \\
\left(\mathrm{g} \cdot \mathrm{m}^{-2}\right)^{2}\end{array}$ & $\begin{array}{l}\text { Sill } \\
\left(\mathrm{g} \cdot \mathrm{m}^{-2}\right)^{2}\end{array}$ & range (m) & $\beta_{0}$ & $\beta_{1}$ & SEE (\%) \\
\hline RG & 0 & 114940 & 11.3 & 1130.4 & 17.9 & 0.09514 \\
OG & 167610 & 215390 & 7.6 & 792.4 & 24.1 & -0.04922 \\
\hline
\end{tabular}


Fig. 4 Empirical variogram of the variable SOC $\left(\mathrm{g} \cdot \mathrm{m}^{-2}\right)$ (dots), a fitted spherical variogram which represents the variogram of the Universal Kriging model residuals (solid line), the empirical variogram of the explanatory variable (crown cover within a buffer of 4 m-width around the sampling point) multiplied by the $\beta_{1}$ coefficient (dotted line) and the linear combination of the fitted spherical variogram and the empirical variogram of the explanatory variable multiplied by the $\beta_{1}$ coefficient (dashed line). The number of pairs of observations were $16,64,122,136$, 194, 246, 226, 226, 282, 264, 260, 212, 276 for 3.5 , 7.2, 12.5, 17.2, 22.2, 27.3, $32.4,37.4,42.2,47.4,52.4$, $57.0,62.4$ distance lags respectively in the more regularly grazed plot (a) and $824,1860,2356,3044$, 4098, 4176, 4632, 3792, 5138, 4282, 3874, 3168, 3214 for $3.3,7.7,12.7,17.2$, 22.2, 27.3, 32.6, 37.3, 42.2, $47.5,52.3,57.3,62.3$ in the occasionally grazed plot (b)
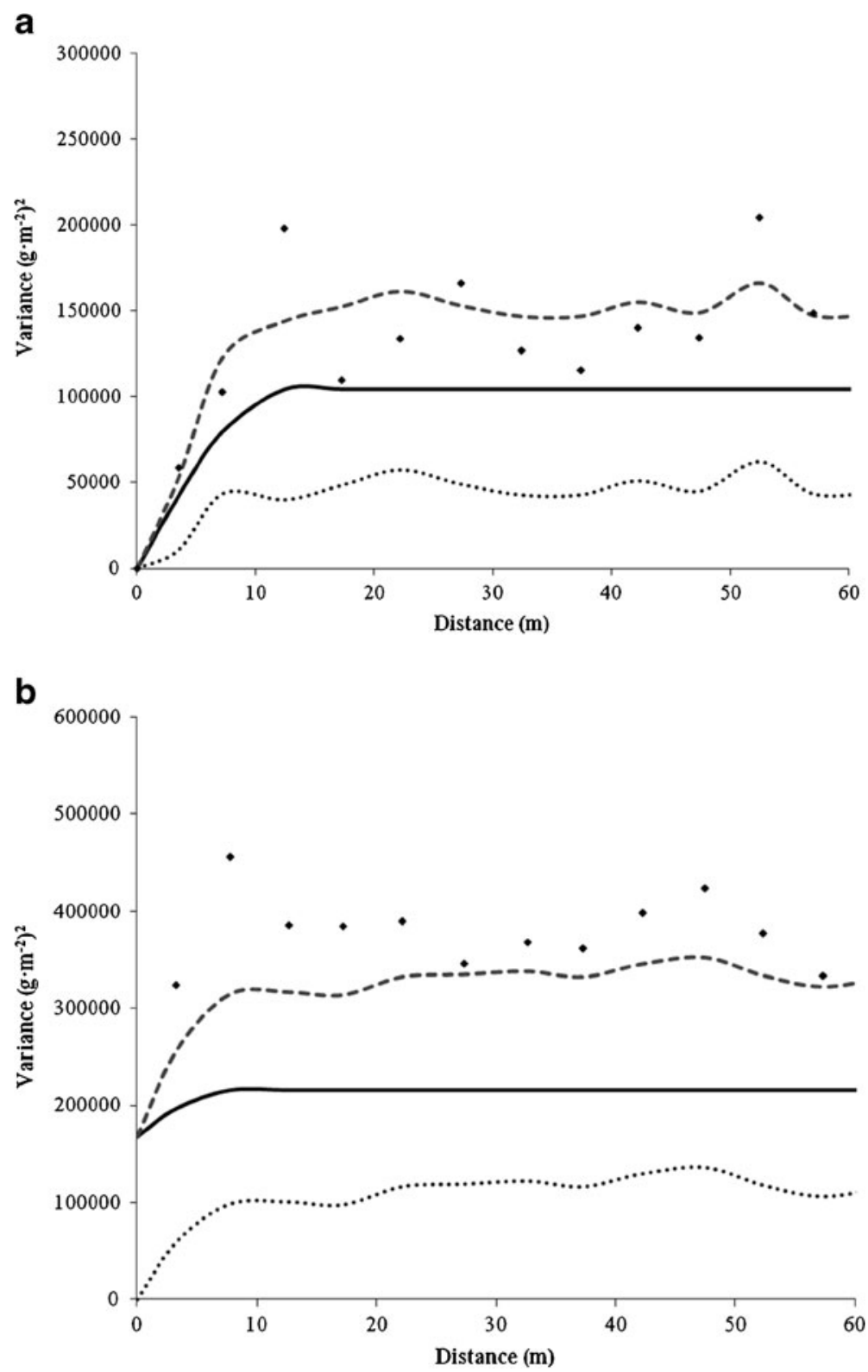

process, which was embraced by the variogram model. The empirical variogram of the SOC stock partially reflected the peaks observed in the variogram of the auxiliary variable (Fig. 4), indicating that tree cover drives part of the spatial pattern of the SOC stock. A noticeable hole effect can be appreciated at distances around $40 \mathrm{~m}$, particularly in the case of the RG plot (Fig. 4).

The Block Universal Kriging gave a significantly higher mean SOC stocks value for the uppermost $5 \mathrm{~cm}$ of the mineral soil in the RG plot $(1237.1 \mathrm{~g}$ $\left.\mathrm{C} \cdot \mathrm{m}^{-2}\right)$ than in the OG plot $\left(1005.4 \mathrm{~g} \mathrm{C} \cdot \mathrm{m}^{-2}\right)$
(Table 5). The area influenced by the Holm oak crowns (i.e. those points located within a $4 \mathrm{~m}$ buffer around the vertical projection of the crown) showed higher block mean SOC values in the RG (1408.0 g $\left.\mathrm{C} \cdot \mathrm{m}^{-2}\right)$ than in the OG plot $\left(1210.8 \mathrm{~g} \mathrm{C} \cdot \mathrm{m}^{-2}\right)$. There were also differences between $\mathrm{RG}$ and $\mathrm{OG}$ in the SOC stocks outside crown influence $\left(1131.6 \mathrm{~g} \mathrm{C} \cdot \mathrm{m}^{-2}\right.$ in $\mathrm{RG}$ and $818.0 \mathrm{~g} \mathrm{C} \cdot \mathrm{m}^{-2}$ in $\left.\mathrm{OG}\right)$.

The highest SOC values were found beneath the canopy. Beyond the vertical projection of the crown, SOC stock values rapidly declined, exhibiting homogeneous values in the rest of the area (Fig. 5). 
Table 5 Block Universal Kriging SOC mean and standard errors for the plot, the tree cover buffering area and the area beyond the tree dripline in the regularly grazed plot (RG) and occasionally grazed plot (OG)

\begin{tabular}{llll}
\hline Plot & $\begin{array}{l}\text { Plot SOC } \\
\text { block mean } \pm \\
\sigma_{U K}\left(\mathrm{~g} \cdot \mathrm{m}^{-2}\right)\end{array}$ & $\begin{array}{l}\text { Beneath crown } \\
\text { SOC block mean } \pm \\
\sigma_{U K}\left(\mathrm{~g} \cdot \mathrm{m}^{-2}\right)\end{array}$ & $\begin{array}{l}\text { Beyond dripline } \\
\text { SOC block } \\
\text { mean } \pm \sigma_{U K}\left(\mathrm{~g} \cdot \mathrm{m}^{-2}\right)\end{array}$ \\
\hline RG & $1237.1 \pm 39.5$ & $1408.0 \pm 43.9$ & $1131.6 \pm 48.5$ \\
OG & $1055.4 \pm 40.6$ & $1210.8 \pm 40.0$ & $818.0 \pm 63.6$ \\
\hline
\end{tabular}

The SOC estimates obtained using Universal Kriging show a low bias (mean SEE of $0.09514 \%$ (RG) and $-0.04922 \%(\mathrm{OG})$ in the cross validation analysis, which indicates the suitability of the proposed model to characterize tree effect on SOC distribution.

\section{Discussion}

Our results revealed a storage capacity of 1050-1237 g $\mathrm{C} \mathrm{m}^{-2}$ in the uppermost $5 \mathrm{~cm}$ of mineral soil alone, while the SOC stocks in the whole soil profile $(125 \mathrm{~cm})$ were estimated to be as high as $2500 \mathrm{~g} \mathrm{C} \mathrm{m}^{-2}$ (Rodeghiero et al. 2011), indicating that roughly $50 \%$ of the SOC is stored in this thin superficial layer. In comparison to other ecosystems in Mediterranean areas such as shrublands, broadleaf forests (Rodríguez-Murillo 2001), or
Fig. 5 Model of predicted soil organic carbon $\left(\mathrm{g} \cdot \mathrm{m}^{-2}\right)$ assessed with Universal Kriging and using crown cover as an ancillary variable (drawn with dotted blue line) within a buffer of $4 \mathrm{~m}$ width around the sampling point for the more regularly grazed plot (a) and for the occasionally grazed plot (b). The triangular markers show the point locations sampled in the two plots with their corresponded measured value of soil organic carbon

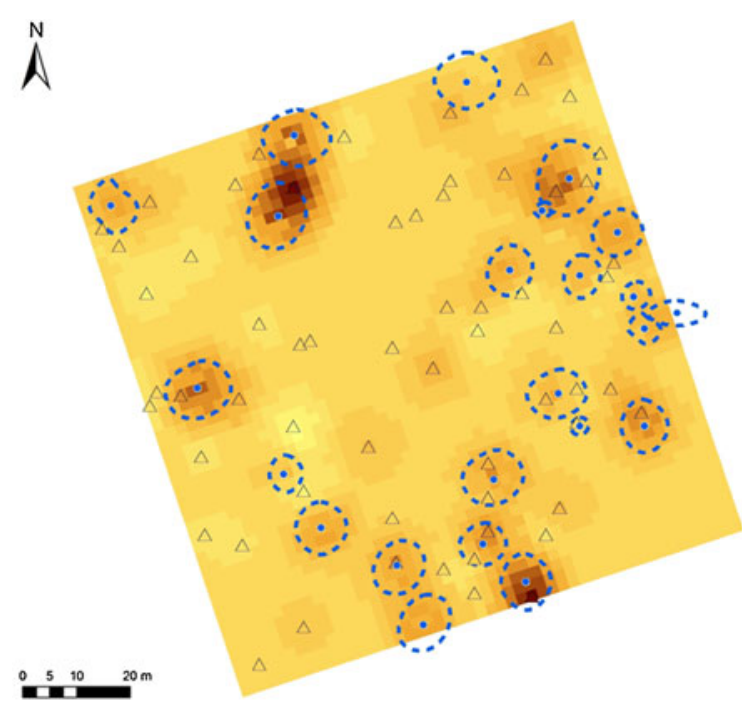

a

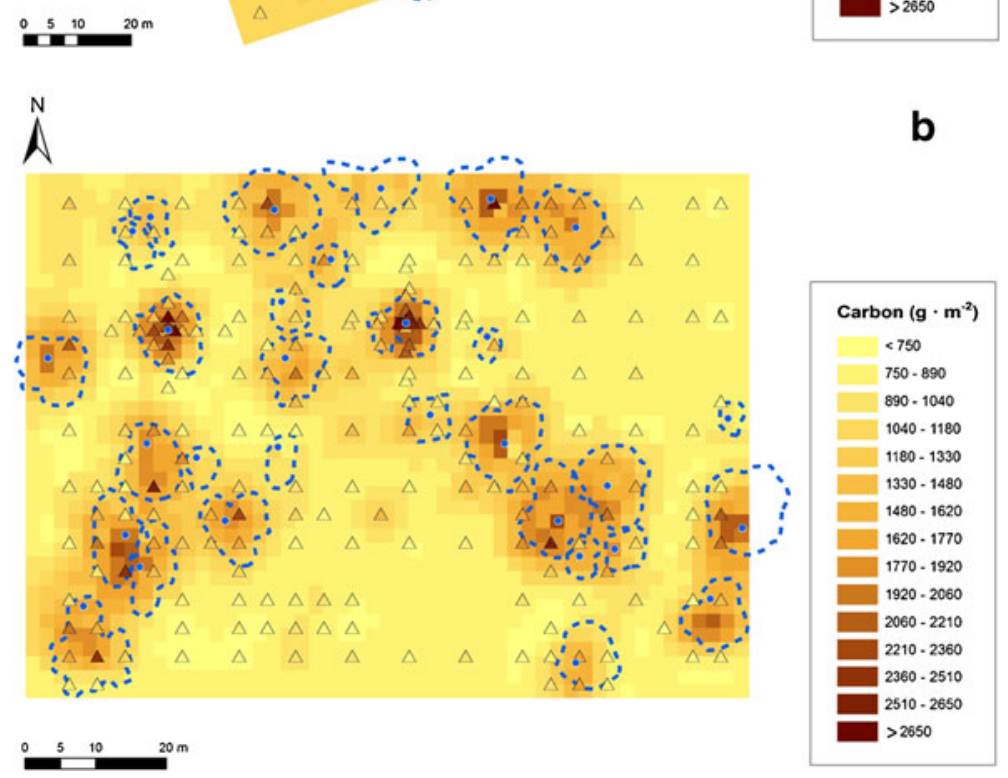

Carbon $\left(g \cdot \mathbf{m}^{-2}\right)$ $<750$ $750-890$ $890 \cdot 1040$ 1040 - 1180 $1180 \cdot 1330$ $1330-1480$ 1480.1620 ए $1620 \cdot 1770$ 1770 - 1920 $1920 \cdot 2060$ 2060 - 2210 2210.2360 $2360-2510$ $2510 \cdot 2650$ - $>2650$ 
Scots pine forests in Spain (Díaz-Pinés et al. 2011; Schindlbacher et al. 2010), the SOC storage in dehesas is relatively low (Rodeghiero et al. 2011), although similar to other Holm oak forests in southern Spain (Chiti et al. 2012). Furthermore, the highest proportion of SOC stored in dehesa systems is allocated in the most sensitive layer, since it is highly exposed to natural or human-induced disturbances such as livestock management or tillage, both common practices in agroforestry systems.

In dehesas, tree crowns directly control both the grass layer and soil features (Gea et al. 2009; Gallardo 2003). Thus, modelling approaches which include the effect of the tree layer on the spatial distribution of SOC are of great interest for managing these agroforestry systems. The results of the present study show that soil beneath the tree crown has higher SOC stocks in comparison to open areas. Furthermore, we show that the probable mechanism which leads to higher SOC stocks is the crown projection. This can be inferred from the positive correlation between the SOC stock and the percentage of tree crown cover, and the positive $\beta_{1}$ coefficient affecting the percentage of tree cover (R4 variable) (Table 4). Similar effects have been detected in other systems comprising scattered trees with herbaceous communities in arid and semiarid environments, where higher soil organic matter, soil water and nutrient contents have been recorded in the proximity of the trees (Gallardo 2003; Jackson and Caldwell 1993). In dehesas, tree crowns are the main source of heterogeneity in soils (Gallardo et al. 2000), so the spatial autocorrelation range of soil characteristics tends to be linked to crown size (Gallardo and Maestre 2008). In the present study, we found that the influence of the trees on soil characteristics extended beyond the crown projection, which supports the findings of previous studies (Gallardo 2003). Similarly, Gea et al. (2009) determined that the influence of trees on the composition of the grass layer extended up to a distance from the trunk of twice the crown radius. The Krx (d) function revealed a positive spatial association between the trees and SOC levels. This association reaches beyond the vertical projection of the crown of the Holm oaks by a distance equal to the crown radius (Fig. 3).

The variograms (Fig. 4) showed that nearly $30 \%$ of the spatial variability in SOC stock was linked to the area of influence of the trees. SOC stocks in dehesas are determined by the balance of inputs (above- and belowground litterfall, livestock) and outputs (soil respiration, animal exports). The tree crowns influence several of these controlling processes and therefore the effects on SOC stocks may be explained by the auxiliary variable incorporated in the Universal Kriging model. Litterfall (both tree litterfall and grass litterfall) is the most important in terms of soil nutrient transfer (Raich and Nadelhoffer 1989). In closed canopy forests, litterfall usually leads to a homogenisation of soils features (Lister et al. 2000). In our study, the low tree density leads to soil heterogeneity due to heterogeneous tree-litterfall rates (about $1000 \mathrm{~g} \cdot \mathrm{C} \mathrm{m}^{-2}$ year $^{-1}$ under the oak crown and negligible beyond the crown). This is coupled with the variability in herbaceous yield beneath and beyond the crown projection and the behaviour of grazers, which is influenced by the tree presence (Escudero et al. 1985).

Besides the influence of the tree cover on $\mathrm{C}$ exports and imports, a scarce and scattered distribution of trees implies heterogeneity in the quantity and quality of light, and the buffering of extreme temperatures (Moreno and Pulido 2008). Soil water content is also interactively influenced, depending on the time of day and season. Therefore, shifts in the micro-climatic environmental conditions under Mediterranean climate lead to shifts in plant species composition (Gallardo 2003; Gea et al. 2009) and different grass production under canopy in comparison with open pasture (Moreno 2008). However, the direction of the interaction between the tree and the herbaceous layers (positive or negative, i.e. facilitation or competition) changes temporally and spatially according to the most limiting ecological factor for plant growth (Gea et al. 2009). Due to this phenomena coupled with the small-scale environmental changes, different mineralization and humification rates may occur in the upper horizon of soils below the tree canopy and within a determined zone of influence beyond the canopy. Thus, a combination of biotic and abiotic factors explains the spatial pattern of the SOC stock and the influence of tree cover identified through our spatial model. In addition, the variograms of the SOC stocks revealed a marked hole effect at distances of around $40 \mathrm{~m}$ (Fig. 4). This evidence proves a certain periodicity in the continuity of the studied variable at this lag (Oliver et al. 1989), which is probably related to the distribution pattern of tree groups. These results agree with preliminary results of research concerning the distribution of individual trees, in which the mean distance between Holm oak clusters was found to be around $40 \mathrm{~m}$ (unpublished). 
In addition to the influence of tree distribution, the observed spatial structures of SOC stocks distribution exhibited intrinsic variability due to local phenomena and other combined processes (physical, chemical or biological) interacting at different scales. The method used in this study for partitioning the variance (Montes and Ledo 2010), shows that $70 \%$ of the SOC variability is due to residual spatial autocorrelation, which extends up to $11.3 \mathrm{~m}$ in $\mathrm{RG}$ and $7.6 \mathrm{~m}$ in OG. The non-spatial variability, defined by the nugget, accounts for $30 \%$ of the variability in the OG plot, whereas is negligible in the case of $\mathrm{RG}$, probably due both to the lack of sampling locations at very short distances and the higher spatial continuity of SOC in this plot. The residual spatial autocorrelation may be due to factors not directly dependent on tree layout, such as soil texture, soil structure, soil $\mathrm{pH}$ or water availability (Kirschbaum 2000), but which affect the quality of the SOC and the soil microbial community quantity and activity (Kandeler et al. 2005). Scale-dependent relationships are common in soil science, as many soil properties result from the same underlying processes interacting at different scales (Gallardo et al. 2000; Gallardo and Covelo 2005). These properties subsequently affect soil fertility and lead to a patchy distribution of grass layer species (Gea et al. 2009). However, the very different nugget in RG and OG shows that livestock management in the dehesa is a key factor of this residual spatial autocorrelation. Livestock activity plays an important role in determining soil structure and functioning of the upper horizons (Peco et al. 2006; San Miguel 2001) by accelerating the turnover of SOC. However, SOC stock values are slightly higher in the RG than in the OG plot, both beneath and beyond the tree crown projection (Fig. 5). Given similar soil fertility, grazers promote more productive grass communities, both in dehesas (San Miguel 2001) and other savannah ecosystems (Veblen 2012). Thus, grazers favour the development of communities comprising species which perform better under non-intensive grazing management (San Miguel 2001) (Sysymbrietaliae in RG vs. Tuberarietalia in OG), which may lead to higher SOC stocks. It is possible, however, that the higher stocking rate is also responsible for the greater range of autocorrelation of SOC levels in RG, since livestock both transport and redistribute nutrients, expanding the area of influence of the tree and its effect of enhancing $\mathrm{C}$ inputs to the soil.

\section{Conclusions}

Our research highlights the positive correlation between tree presence and SOC stocks up to distances of $8 \mathrm{~m}$ from the trees; roughly a crown radius distance beyond the dripline. The effect of the trees on SOC absorbed $30 \%$ of the variance in the Universal Kriging model. The residual variance of the SOC displayed a much more pronounced spatial structure under regular grazing conditions, where the nugget effect was almost negligible and the autocorrelation range extends up to $11.3 \mathrm{~m}$, while under occasional grazing conditions, the autocorrelation range was $7.6 \mathrm{~m}$ and the non-spatially structured variance absorbed more than $50 \%$ of total variance. Tree crown projection was the main mechanism leading to higher SOC stocks in this dehesa, likely due to changing environmental conditions beneath the tree cover.

Acknowledgements We thank Remedios Cubillo and Beatriz Ortiz for laboratory support and Emilien Simonot for his valuable previous work. We would like to thank the managers of El Dehesón, and particularly Celia López-Carrasco, for their practical support. The authors wish to express their appreciation to Ms Pru Brooke-Turner and Mr Adam Collins for their linguistic assistance. This study has been partially funded by the projects AGL2010-16862 and SUM2006-00034-C02 and the Ramón y Cajal Program from the Spanish Ministry of Education, and preliminary results have been presented in the frame of COST Action 639 (BurnOut).

\section{References}

Barba L, Carretero JM, García A, García J, López A, Mainer C, Olea L, Palacios E, Ruiz E, San Miguel A, Serrada R, Solano JM, Velasco A (2008) Plan Nacional de Dehesas. Ministerio de Medio Ambiente, Medio Rural y Marino, Madrid

Blake GR, Hartge KH (1986) Bulk Density. In: Klute A (ed) Methods of soil analysis. Part 1: Physical and mineralogical methods, 5th edn. Soil Science Society of America, Madison, WI, pp 363-375

Borcard D, Legendre P, Drapeau P (1992) Partialling out the spatial component of ecological variation. Ecology 73:1045-1055. doi:10.2307/1940179

Carreiras JMB, Pereira JMC, Pereira JS (2006) Estimation of tree canopy cover in evergreen oak woodlands using remote sensing. Forest Ecol Manag 223:45-53. doi:10.1016/ j.foreco.2005.10.056

Chen F, Kissell DE, West LT, Adkins W (2000) Field-scale mapping of surface soil organic carbon using remotely sensed imagery. Soil Sci Soc Am J 64:746-753. doi:10.2136/ sssaj2000.642746x 
Chiti T, Díaz-Pinés E, Rubio A (2012). Soil organic carbon stocks of conifers, broadleaf and evergreen broadleaf forests of Spain. Biology and Fertility of Soils (in press) doi 10.1007/s00374-012-0676-3

Cressie NAC (1993) Statistics for spatial data. Wiley, New York

Díaz-Pinés E, Rubio A, Van Miegroet H, Benito M, Montes F (2011) Does tree species composition control soil organic carbon pools in Mediterranean mountain forests? Forest Ecol Manag 262:1895-1904. doi:10.1016/j.foreco.2011.02.004

Ellert B, Bettany JR (1995) Calculation of organic matter and nutrients stored in soils under contrasting management regimes. Can J Soil Sci 75:529-538. doi:10.4141/cjss95075

Escudero A, García B, Gómez JM, Luis E (1985) The nutrient cycling in Quercus rotundifolia and Quercus pyrenaica ecosystems (dehesas) of Spain. Acta Oecol Oecol Plant 6:73-86

Escudero A, Del Arco JM, Garrido MV (1992) The efficiency of nitrogen retranslocation from leaf biomass in Quercus ilex ecosystems. Vegetatio 99-100:225-237. doi:10.1007/ BF00118229

FAO (2004) Carbon sequestration in dryland soils. World soil resources reports 102 . Rome

Gallardo A (2003) Effect of tree canopy on the spatial distribution of soil nutrients in a Mediterranean Dehesa. Pedobiologia 47:117-125. doi:10.1078/0031-4056-00175

Gallardo A, Covelo F (2005) Spatial pattern and scale of leaf N and $\mathrm{P}$ concentration in a Quercus robur population. Plant Soil 273:269-277. doi:10.1007/s11104-004-7943-5

Gallardo A, Maestre FT (2008) Métodos geoestadísticos para el análisis de datos ecológicos espacialmente explícitos. In: Maestre FT, Escudero A, Bonet A (eds) Introducción al Análisis Espacial de Datos en Ecología y Ciencias Ambientales: Métodos y Aplicaciones. Universidad Rey Juan Carlos, pp 215-272

Gallardo A, Merino J (1998) Soil nitrogen dynamics in response to carbon increase in a Mediterranean shrubland of SW Spain. Soil Biol Biochem 30:1349-1358. doi:10.1016/ S0038-0717(97)00265-4

Gallardo A, Rodríguez-Saucedo JJ, Covelo F, Fernández-Alés R (2000) Soil nitrogen heterogeneity in a Dehesa ecosystem. Plant Soil 222:71-82. doi:10.1023/A:1004725927358

Garrity D, Okono A, Grayson M, Parrott S (eds) (2006) World agroforestry into the future. World Agroforesty Centre, Nairobi

Gea G, Montero G, Cañellas I (2009) Changes in limiting resources determine spatio-temporal variability in tree-grass interactions. Agroforest Syst 76:375-387. doi:10.1007/s10457009-9211-4

Goovaerts P (1999) Geostatistics in soil science: state-of-the-art and perspectives. Geoderma 89:1-45. doi:10.1016/S00167061(98)00078-0

Goreaud F, Pélissier R (1999) On explicit formulas of edge effect correction for Ripley's K-function. J Veg Sci 10:433-438. doi: $10.2307 / 3237072$

Gotway CA, Stroup WW (1997) A generalized linear model approach to spatial data analysis and prediction. J Agr Biol Environ Stat 2:157-178. doi:10.2307/1400401

Harville DA (1974) Bayesian inference for variance components using only error contrasts. Biometrika 61:383-385. doi:10.1093/biomet/61.2.383
He F, Legendre P, LaFrankie JV (1996) Spatial pattern of diversity in a tropical rain forest in Malaysia. J Biogeogr 23:57-74. doi:10.1046/j.1365-2699.1996.00976.x

IPCC (2007) Climate change 2007: synthesis report summary for policymakers. Paper of the intergovernmental panel on climate change. IPCC Secretariat, Geneve

IUSS Working Group WRB (2007) World reference base for soil resources 2006. First update 2007. World soil resources reports no. 103. FAO, Rome

Jackson RB, Caldwell MM (1993) Geostatistical patterns of soil heterogeneity around individual perennial plants. J Ecol 81:683-692. doi:10.2307/2261666

Joffre R, Rambal S (1988) Soil water improvement by trees in the rangelands of southern Spain. Oecologia Plantarum 9:405-422

Joffre R, Rambal S, Ratte JP (1999) The dehesa system of southern Spain and Portugal as a natural ecosystem mimic. Agroforest Syst 45:57-79. doi:10.1023/A:1006259402496

Kandeler E, Stemmer M, Gerzabek MH (2005) Role of microorganisms in carbon cycling in soils. In: Buscot F, Varma A (eds) Microorganisms in soils: roles in genesis and functions. Springer, Berlin, Heidelberg, pp 139-157

Kirschbaum MUF (2000) Will changes in soil organic carbon act as a positive or negative feedback on global warming? Biogeochemistry 48:21-51. doi:10.1023/A:1006238902976

Lark RM (2000) A geostatistical extension of the sectioning procedure for disaggregating soil information to the scale of functional models of soils processes. Geoderma 95:89112. doi:10.1016/S0016-7061(99)00086-5

Laslett GM, McBratney AB, Pahl PJ, Hutchinson MF (1987) Comparison of several spatial prediction methods for soil pH. J Soil Sci 38:325-341. doi:10.1111/j.13652389.1987.tb02148.x

Li Y, Tenhunen J, Mirzaei H, Hussain MZ, Siebicke L, Foken T, Otieno D, Schmidt M, Ribeiro N, Aires L, Pio C, Banza J, Pereira J (2008) Assessment and up-scaling of CO2 exchange by patches of the herbaceous vegetation mosaic in a Portuguese cork oak woodland. Agr Forest Meteorol 148:1318-1331. doi:10.1016/j.agrformet.2008.03.013

Lister AJ, Mou PM, Jones RH, Mitchell RJ (2000) Spatial patterns of soil and vegetation in a 40-year-old slash pine (Pinus elliottii) forest in the Coastal Plain of South Carolina, U.S.A. Can J For Res 30:145-155 doi:10.1139/x99-196

Loosmore NB, Ford ED (2006) Statistical inference using the G or K point pattern spatial statistics. Ecology 87: 19251931. http://dx.doi.org/10.1890/0012-9658(2006)87[1925: SIUTGO]2.0.CO;2]

Matheron G (1973) The intrinsic random functions and their applications. Adv Appl Probab 5:439-468

Montes F, Cañellas I (2007) The spatial relationship between post-crop remaining trees and the establishment of saplings in Pinus sylvestris stands in Spain. Appl Vegetation Sci 10:151-160. doi:10.1111/j.1654-109X.2007. tb00513.x

Montes F, Ledo A (2010) Incorporating environmental and geographical information in forest data analysis: a new fitting approach for universal kriging. Can J For Res 40:1852-1861. doi:10.1139/X10-131

Moreno G (2008) Response of understorey forage to multiple tree effects in Iberian dehesas. Agr Ecosyst Environ 123:239-244. doi:10.1016/j.agee.2007.04.006 
Moreno G, Obrador JJ (2007) Effects of trees and understorey management on soil fertility and nutritional status of holm oaks in Spanish dehesas. Nutr Cycl Agroecosys 78:253264. doi:10.1007/s10705-007-9089-3

Moreno G, Pulido F. (2008) The functioning, management and persistence of dehesas. In: Rigueiro-Rodríguez A, McAdam J, Mosquera-Losada MR (eds) Agroforestry in Europe. Current Status and Future Prospects Springer Netherlands, pp $127-160$

Moreno G, Obrador JJ, García A (2007) Impact of evergreen oaks on soil fertility and crop production in intercropped dehesas. Agr Ecosyst Environ 119:270-280. doi:10.1016/ j.agee.2006.07.013

Mueller TG, Pierce FJ (2003) Soil carbon maps: enhancing spatial estimates with simple terrain attributes at multiple scales. Soil Sci Soc Am J 67:258-267. doi:10.2136/ sssaj2003.2580

Nelson DW, Sommers LE (1996) Total carbon, organic carbon, and organic matter. In: Sparks DL (ed) Methods of soil analysis. Part 3: chemical methods 3 rd edn. Soil Science Society of America. Madison, WI. Book Series, No. 5, pp 961-1010

Oliver M, Webster R, Gerrard J (1989) Geostatistics in physical geography. Part II: Applications. Transactions of the Institute of British Geographers, New Series, Vol. 14, No. 3, pp 270-286

Peco B, Sánchez AM, Azcárate FM (2006) Abandonment in grazing systems: consequences for vegetation and soil. Agr Ecosyst Environ 113:284-294. doi:10.1016/j.agee.2005.09.017

Pinto-Correia T (1993) Landscape monitoring and management in European rural areas: Danish and Portuguese case studies of landscape patterns and dynamics. Dissertation, University of Copenhagen

Raich JW, Nadelhoffer KJ (1989) Belowground carbon allocation in forest ecosystems: Global trends. Ecology 70:1346-1354

Ripley BD (1977) Modelling spatial patterns (with discussion). J Roy Stat Soc 2:172-212
Rodeghiero M, Rubio A, Díaz-Pinés E, Romanyà J, Marañón S, Levy G, Sebastiá T, Fernández-Getino AP, Karyotis T, Chiti T, Sirca C, Martins A, Madeira M, Zhiyanski M, Gristina L (2011) Mediterranean ecosystems. In: Jandl R, Olssons M, Rodeghiero M (eds) Soil carbon in sensitive european ecosystems. John Wiley \& Sons, West Sussex, UK

Rodríguez-Murillo JC (2001) Organic carbon content under different types of land use and soil in peninsular Spain. Biol Fer Soils 33:53-61. doi:10.1007/s003740000289

Rovira $\mathrm{P}$, Romanyà $\mathrm{J}$, Rubio $\mathrm{A}$, Roca $\mathrm{N}$, Alloza $\mathrm{JA}$, Vallejo R (2007) Estimación del carbono orgánico en los suelos peninsulares españoles. In: Bravo F (ed) El papel de los bosques en la mitigación del cambio climático. Fundación Gas Natural, Barcelona, pp 197-222

San Miguel A (2001) Pastos naturales españoles. Fundación Conde del Valle de Salazar, Ediciones Mundi-Prensa, E.T.S.I. Montes, Madrid

Schindlbacher A, de Gonzalo C, Díaz-Pinés E, Gorría P, Matthews B, Inclán R, Zechmeister-Boltenstern S, Rubio A, Jandl R (2010) Temperature sensitivity of forest soil organic matter decomposition along two elevation gradients. J Geophys Res 115(G03018):1-10. doi:10.1029/2009JG001191

Scholes RJ, Archer SR (1997) Tree-grass interactions in savannas. Annu Rev Ecol Syst 28:517-544. doi:10.1146/ annurev.ecolsys.28.1.517

Stein A, Corsten LCA (1991) Universal kriging and cokriging as a regression procedure. Biometrics 47:575-587. doi:10.2307/ 2532147

Veblen KE (2012) Savanna glade hotspots: Plant community development and synergy with large hervibores. J Arid Environ 78:119-127. doi:10.1016/j.jaridenv.2011.10.016

Wiegand T, Moloney KA (2004) Rings, circles and null-models for point pattern analysis in ecology. Oikos 10:209-229. doi:10.1111/j.0030-1299.2004.12497.x

Young A (1997) Agroforestry for soil management. CAB International, Wallingford, pp 29 and 34-37 